\title{
Lock, stock, and barrel: a comprehensive assessment of the determinants of terror
}

\section{Journal Article}

Author(s):

Gassebner, Martin; Lüchinger, Simon

Publication date:

2011-12

Permanent link:

https://doi.org/10.3929/ethz-b-000045046

Rights / license:

In Copyright - Non-Commercial Use Permitted

Originally published in:

Public Choice 149(3-4), https://doi.org/10.1007/s11127-011-9873-0 


\title{
Lock, stock, and barrel: a comprehensive assessment of the determinants of terror
}

\author{
Martin Gassebner • Simon Luechinger
}

Received: 14 June 2011 / Accepted: 10 August 2011

(C) Springer Science+Business Media, LLC 2011

\begin{abstract}
We assess the robustness of previous findings on the determinants of terrorism. Using extreme bound analysis, the three most comprehensive terrorism datasets, and focusing on the three most commonly analyzed aspects of terrorist activity, i.e., location, victim, and perpetrator, we re-assess the effect of 65 proposed correlates. Evaluating around 13.4 million regressions, we find 18 variables to be robustly associated with the number of incidents occurring in a given country-year, 15 variables with attacks against citizens from a particular country in a given year, and six variables with attacks perpetrated by citizens of a particular country in a given year.
\end{abstract}

Keywords Causes of terrorism · Poverty and terrorism $\cdot$ Panel estimations $\cdot$ Extreme bounds analysis

JEL Classification D74 $\cdot$ F51 $\cdot$ F52 $\cdot$ H56 $\cdot$ K42

\section{Introduction}

Why? Why us? Heinous terrorist attacks create an urge to understand the causes of terrorism. Insights can be gained by examining the correlates of terrorism at the country level. The tragic events of September 11, 2001, and the recent wave of terrorist attacks have triggered a vast amount of empirical research in this vein. However, only very few robust findings have emerged so far and there is no consensus on the causes of terrorism. Previous studies

M. Gassebner $(\bowtie) \cdot$ S. Luechinger

KOF Swiss Economic Institute, ETH Zurich, Weinbergstrasse 35, 8092 Zurich, Switzerland

e-mail: gassebner@kof.ethz.ch

S. Luechinger

University of Lucerne, Lucerne, Switzerland

e-mail: simon.luechinger@unilu.ch

M. Gassebner

CESifo Munich, Munich, Germany 
differ along various dimensions, most notably the set of explanatory variables, the terror dataset used, the estimation technique, the period considered, and the aspect of terrorism analyzed. Therefore, it is difficult to weed out contradictions and inconsistencies.

This paper takes stock of the literature and re-assesses the effect of most suggested variables using a consistent set of data and methods. We apply extreme bound analysis (EBA) as suggested by Leamer (1983) and Levine and Renelt (1992) and modified by Sala-iMartin (1997) to test the robustness of 65 proposed correlates. We estimate the effects using the three most comprehensive datasets (ITERATE, Global Terrorism Database (GTD), and Memorial Institute for the Prevention of Terrorism (MIPT)) and focusing on the three key aspects (location, victim, and perpetrator) of terrorism. This exercise yields results on two fronts: First, it allows us to find truly robust correlates-if there are any. Second, it reveals the reasons behind the contradictions in the current literature. In this way, the paper provides policy relevant information and helps to place future research in the field on a firmer base.

Evaluating around 6.8 million regressions with the number of terrorist attacks occurring in a particular country and year, we find that economic freedom, physical integrity rights, law and order, and infant mortality rates are negatively associated with terrorism, while population, military expenditures and personnel, internal and internationalized internal wars, guerrilla wars, strikes, government fractionalization, urbanization, foreign portfolio investments, OECD membership, political proximity to the United States as well as religious and ethnic tensions are positively associated with the occurrence of terrorism.

Around 4.5 million regressions with the number of terrorist attacks against citizens from a particular country reveal a similar set of robust correlates: Economic freedom, physical integrity rights, primary goods exports, large population shares of young people, are negatively related to terrorism-GDP per capita, population, military expenditures, internal and internationalized internal wars, guerrilla wars, OECD membership, political proximity to the United States, and religious and ethnic tension are positively related to terrorism.

Finally, a relatively small number of variables are robustly associated with the number of terrorist attacks perpetrated by the citizens of a particular country. According to around 2.2 million regressions, these are economic freedom, physical integrity rights, and the number of telephone mainlines (all negatively associated) as well as internationalized wars and centrist governments (positively associated).

The short list of robust correlates implies that some of the findings are specific to the context - the dataset, the empirical model or both. Significant determinants in plausible and well-specified models turn insignificant when faced with the rigors of being tested alongside many other plausible variables.

However, four caveats are in order. First, some variables may fail our test because they are poor proxies for otherwise strong theories of terrorism. Second, for some of the theories put to the test, some of the variables in the vector of controls are "bad controls," i.e., some of the variables might just as well be outcome or mediator variables in the notional experiment at hand (Angrist and Pischke 2009: 64-69). Third, our empirical setup forces us to restrict ourselves to reduced form estimations. Thus we cannot account for any structural relationships. Finally, some of the regressors are arguably endogenous because of omitted variables, simultaneity, measurement errors in regressors or sample selection bias. The resulting inconsistencies may affect the parameter estimates for all variables in the model. ${ }^{1}$

Where does all this leave us? On the positive side, our analysis uncovers some truly robust correlates. These correlates should prominently feature in future theoretical and empirical

${ }^{1}$ See, e.g., Hoover and Perez (2004) for a critique of the EBA. 
work on terrorism. On the negative side, our results show just how sensitive are some of the previously reported results. Empirical research on terrorism would greatly gain, therefore, if empirical models are rigorously justified and if the robustness of results is systematically assessed.

The paper proceeds as follows. Section 2 provides a brief review of the literature to set the stage for the empirical analysis. Section 3 describes the details of the empirical method and Sect. 4 presents the results. Section 5 concludes.

\section{Background}

Empirical terrorism research is a growth industry. A comprehensive literature review is, therefore, beyond the scope of this paper. ${ }^{2}$ Instead, we outline the main lines of research in the field. ${ }^{3}$

A long-standing question concerns the relationship between terrorism and democracy (among others, Crenshaw 1981; Sandler 1995; Enders and Sandler 2006a). Two opposing views have been put forward. On the one hand, the intrinsic freedoms and respect for civil liberties of democratic societies are enabling and permissive factors providing a favorable environment for terrorism. On the other hand, democracies allow dissenters to express their grievances by legal and peaceful means. There are, thus, two countervailing effects of democracy: Democracy lowers the direct costs of waging terrorist campaigns, but at the same time increases relative costs (Frey and Luechinger 2003).

In a pioneering study, Eubank and Weinberg (1994) took these competing hypotheses to the data. They found that democracies are more likely to harbor terrorist groups than autocracies. However, the number of terrorist groups is a poor measure for terrorist activity and prone to reporting bias (e.g., Sandler 1995). According to two follow-up studies (Eubank and Weinberg 2001; Weinberg and Eubank 1998), there is a positive or a U-shaped relationship between the degree of democracy and the number of terrorist incidents in a country if incidents are assigned to countries based on the location of the incidence, a positive relationship if incidents are assigned to countries based on nationality of victims and an inverted U-shaped relationship if incidents are assigned to countries based on nationality of perpetrators. These results highlight two important ideas. First, it is important to differentiate between location- and perpetrator-aspects of terrorism (see also Basuchoudhary and Shughart 2010). Arguably, the enabling and permissive factors of democracy are relevant regarding where an attack takes place while the factors of political access are relevant regarding who resorts to terrorism. Second, given the countervailing factors of democracy, the relationship between terrorism and democracy may well be non-linear.

Of the 43 studies reviewed for this paper, 40 include some measure of democracy (e.g., Blomberg and Hess 2008b; Blomberg and Rosendorff 2009; Drakos and Gofas 2006b; Eyerman 1998; Li 2005; Piazza 2008b), political rights (e.g., Abadie 2006) or civil liberties (e.g., Krueger and Laitin 2008; Krueger and Maleckova 2003). Taking a broad-brush view, terrorism seems to be positively associated with democracy in studies on terror-locations and

\footnotetext{
${ }^{2}$ For an overview and further references on the economics of terrorism, see, e.g., Sandler and Enders (2004, 2008), Enders and Sandler (2006a), Frey et al. (2007), Enders (2007), Krueger (2007), Sandler and Arce (2007), Krieger and Meierrieks (2011) and Shughart (2011).

${ }^{3}$ In a working paper version of this paper, we report the details such as sample period and size, terrorist indicator and dataset, estimation technique, and main findings of 43 studies (Gassebner and Luechinger 2011; Table A1).
} 
negatively in studies on perpetrators. However, there are a number of studies with contradictory findings and many others find no significant relationship at all. Several studies model non-linear effects by including squared terms. Since the usual test statistics are invalid for interaction terms and, thus, squared terms in non-linear regressions such as negative binomial regressions (Ai and Norton 2003; Greene 2010), it is not straightforward to interpret these results. Exceptions are Abadie (2006) and Goldstein (2005) who find evidence for a U-shaped relationship between political rights and terrorism risk using linear models.

A widely held belief by academics, politicians, and journalists alike holds that terrorism is rooted in economic grievances (for references, see Krueger and Maleckova 2003). For example, President Bush (2002) explained at a U.N. development conference: "We fight poverty because hope is an answer to terror". President Obama (cited in The Economist 2010) concurs: "Extremely poor societies [...] provide optimal breeding grounds for disease, terrorism and conflict." In the wake of the suicide attack on Moscow airport on January 24, 2011, President Medvedev (2011) similarly argued: "We must do everything possible to influence [...] the socioeconomic roots of terrorism: poverty, unemployment, illiteracy, and orphanhood, and to ensure that global development becomes stable, secure and fair."

Current evidence based on measures of economic development such as GDP and GDP per capita (e.g., Abadie 2006; Berman and Laitin 2008; Blomberg and Hess 2008a; Blomberg and Rosendorff 2009; Tavares 2004), the UN human development index (e.g., Bravo and Dias 2006; Piazza 2006), poverty indices (e.g., Kurrild-Klitgaard et al. 2006), literacy and school enrollment rates (e.g., Blomberg and Hess 2008a; Krueger and Maleckova 2003; Kurrild-Klitgaard et al. 2006), infant mortality rates and life expectancy (e.g., Drakos and Gofas 2006a; Kurrild-Klitgaard et al. 2006), calorie intake and telephone mainlines (e.g., Lai 2007; Piazza 2006) offers only weak support for this hypothesis. Studies that account for attack location and victim identities find-with a few exceptions-either no association or a positive association between economic development and terrorism. More encouraging are studies looking at perpetrators. Several studies document a negative relationship between a country's state of economic development and the number of attacks perpetrated by its citizens. But again, some studies report opposite findings and a large number of studies report non-results.

There are many variations on the theme. First, economic grievances due to changes in economic activity (GDP growth, contraction periods) (e.g., Blomberg et al. 2004; Krueger and Laitin 2008), unemployment rates (e.g., Feldmann and Perälä 2004; Goldstein 2005) or inflation (e.g., Feldmann and Perälä 2004) may be important for terrorism. Second, inequality may matter (e.g., Abadie 2006; Piazza 2006). Third, social safety nets and redistributive policies at the national level and aid at the international level may alleviate grievances and, thus, reduce terrorism (e.g., Azam and Delacroix 2006; Azam and Thelen 2008; Burgoon 2006; Crenshaw et al. 2007; Neumayer and Plümper 2009; Robison et al. 2006). Fourth, economic regulation may protect the interest of insiders at the cost of reducing opportunities for outsiders (e.g., Basuchoudhary and Shughart 2010; Kurrild-Klitgaard et al. 2006; Piazza 2008b). Fifth, globalization may break up existing structures and thereby provide new opportunities for formerly excluded groups (e.g., Blomberg and Hess 2008b; Blomberg and Rosendorff 2009; Li and Schaub 2004). Finally, similar to other forms of political violence, terrorism may be related to an abundance of natural resources (Sambanis 2008; Tavares 2004).

Only a few of these hypotheses are borne out by the data. There is a very clear and robust negative relationship between terrorism and globalization. Open countries are, ceteris paribus, less prone to terrorist attacks and their citizens are less likely to be victims or perpetrators of terrorist attacks. In studies on terror-locations, there is contested evidence for a 
negative relationship between welfare policies and terrorism (Burgoon 2006; Crenshaw et al. 2007) and some evidence for the resource curse hypothesis. Studies of perpetrator countries provide conflicting evidence regarding aid and some evidence for a negative relationship between terrorism and economic freedoms.

The positive association between urbanization and terrorism documented in several studies is little surprising for scholars of terrorism. It has long been observed that urbanization is conducive to terrorism (Crenshaw 1981).

Aspects of demography and ethnicity also feature prominently in the literature. Trivially, large countries provide many targets and a larger pool of potential victims and perpetrators. Thus, population size is consistently positively correlated with terrorism. Beyond this scale effect, countries with growing population seem to be plagued by less (e.g., Dreher and Fischer 2010) — and countries with young populations by more terrorism (Tavares 2004; Urdal 2006). ${ }^{4}$

Notorious cases of sectarian violence and separatist terrorism suggest that ethnically, linguistically or religiously fragmented societies are a fertile ground for terrorism. The preponderance of evidence points indeed to a positive relationship between ethnic/linguistic fractionalization/tensions and terrorism. In contrast, terrorism seems not to be related to religious fractionalization/tensions within countries according to the existing literature. Most of the previous studies analyzing the relationship between ethnicity and terrorism frame their theoretical arguments in terms of ethnic tensions but test the theories with measures of ethnic fractionalization. A notable exception is Basuchoudhary and Shughart (2010) who use a measure of ethnic tensions. In the analysis at hand, we follow their lead and use this theoretically sounder measure. The variable on ethnic tensions has the additional advantage in our panel setting of being time variant.

Several researchers expect terrorism to be associated with other forms of political violence, conflicts and wars. First, terrorism can be often a strategy of the weaker belligerent in asymmetric warfare (both in intra- and interstate conflicts). Second, demonstrations, strikes and riots may be expressions of the same grievances that provide the background of terrorist campaigns. Third, civil wars provide an ideal training ground for prospective terrorists (Campos and Gassebner 2009). Finally, some observers of terrorism reckon international terrorism to be "someone else's civil war" (Doran 2002). It is aimed at provoking overreactions that drive people into the arms of the terrorists. Overall, these conjectures are supported by the available evidence. Countries with internal conflicts experience and produce more terrorism than other countries (e.g., Campos and Gassebner 2009; Piazza 2007, 2008a; Testas 2004). The evidence for interstate conflicts and wars points in the same direction although the evidence is somewhat weaker (e.g., Braithwaite and Li 2007; Dreher and Fischer 2010; Koch and Cranmer 2007; Piazza 2008a; Walsh and Piazza 2010).

In addition to variables capturing political freedoms, economic grievances, demographic and ethnic factors as well as internal and external conflicts, researchers proposed a large variety of other potential correlates (see Table 1). But findings that are presented as statistically significant in the presence of some variables may not be significant in the presence of other variables proposed by different scholars. Therefore, we suggest testing the bounds of the significance of all previously considered variables.

\footnotetext{
${ }^{4}$ Krueger and Maleckova (2009: 1536) do not find a strong effect of this so called "youth bulge."
} 
Table 1 Variables

GDP per capita, log

Definition: log of GDP per capita based on PPP (constant 2005 international \$)

Source: World Bank (2009)

Proposed by: Abadie (2006), Azam and Delacroix (2006), Azam and Thelen (2008),

Basuchoudhary and Shughart (2010), Berman and Laitin (2008), Blomberg and Hess (2008a, 2008b),

Blomberg and Rosendorff (2009), Blomberg et al. (2004), Braithwaite and Li (2007),

Bravo and Dias (2006) ${ }^{\mathrm{b})}$, Burgoon (2006) ${ }^{\mathrm{b})}$, Campos and Gassebner (2009), Crenshaw et al. (2007),

Dreher and Fischer (2010, 2011), Dreher and Gassebner (2008), Eyerman (1998), Goldstein (2005),

Koch and Cranmer (2007) ${ }^{\mathrm{b})}$, Krueger and Laitin (2008), Krueger and Maleckova (2003),

Kurrild-Klitgaard et al. (2006), Lai (2007), Li and Schaub (2004), Li (2005),

Neumayer and Plümper (2009), Piazza (2006, 2008a, 2008b) ${ }^{\text {b) }}$, Piazza (2007) ${ }^{\mathrm{a})}$,

Plümper and Neumayer (2010), Robison et al. (2006), Sambanis (2008), Tavares (2004), Testas (2004),

Urdal (2006), Walsh and Piazza (2010)

Partial Democracy/Democracy

Definition: 1 if Freedom House score $\leq 2.5$ (full democracy); 1 if score 3-5 (partial democracy)

Source: Freedom House (2009a)

Proposed by: Abadie (2006) ${ }^{\mathrm{c})}$, Basuchoudhary and Shughart (2010), Blomberg and Hess (2008a, 2008b), Blomberg and Rosendorff (2009), Blomberg et al. (2004), Braithwaite and Li (2007),

Bravo and Dias (2006) ${ }^{\mathrm{e}}$, Burgoon (2006), Campos and Gassebner (2009), Crenshaw et al. (2007),

Drakos and Gofas (2006a, 2006b), Dreher and Fischer (2010, 2011), Dreher and Gassebner (2008),

Eubank and Weinberg (2001), Eyerman (1998), Feldmann and Perälä (2004) ${ }^{\mathrm{c}), d)}$, Goldstein (2005) ${ }^{\mathrm{c}}$,

Koch and Cranmer (2007), Krueger and Laitin (2008) $)^{\text {d) }}$, Krueger and Maleckova (2003) ${ }^{\text {d) }}$,

Kurrild-Klitgaard et al. (2006), Lai (2007), Li and Schaub (2004), Li (2005) $)^{\mathrm{e})}$,

Neumayer and Plümper (2009), Piazza (2006, 2007, 2008b), Piazza (2008a) $)^{\text {e), }}$

Plümper and Neumayer (2010), Robison et al. (2006) ${ }^{\text {c), d) }}$, Sambanis (2008), Tavares (2004) ${ }^{\text {c) }}$,

Testas (2004), Urdal (2006), Walsh and Piazza (2010), Weinberg and Eubank (1998)

Population, $\log$

Definition: $\log$ of total population

Source: World Bank (2009)

Proposed by: Azam and Delacroix (2006), Azam and Thelen (2008), Braithwaite and Li (2007), Burgoon (2006), Campos and Gassebner (2009), Crenshaw et al. (2007), Dreher and Fischer (2010, 2011), Dreher and Gassebner (2008), Eyerman (1998), Koch and Cranmer (2007),

Krueger and Laitin (2008), Krueger and Maleckova (2003), Lai (2007), Li and Schaub (2004),

Li (2005), Neumayer and Plümper (2009), Piazza (2006, 2007, 2008a, 2008b),

Plümper and Neumayer (2010), Robison et al. (2006), Sambanis (2008), Urdal (2006),

Walsh and Piazza (2010)

GDP growth

Definition: Annual percentage growth rate of GDP at market prices (constant local currency)

Source: World Bank (2009)

Proposed by: Blomberg et al. (2004), Campos and Gassebner (2009), Drakos and Gofas (2006a), Dreher and Fischer (2010), Dreher and Gassebner (2008), Feldmann and Perälä (2004),

Krueger and Laitin (2008), Kurrild-Klitgaard et al. (2006), Li (2005), Piazza (2006), Tavares (2004), Urdal (2006)

Infant mortality rate

Definition: Infant deaths within the first year per 1000 live births

Source: World Bank (2009)

Proposed by: Kurrild-Klitgaard et al. (2006), Urdal (2006)

Life expectancy

Definition: Life expectancy at birth, total (years)

Source: World Bank (2009)

Proposed by: Drakos and Gofas (2006a) 
Table 1 (part 2)

Telephone

Definition: No. of telephone mainlines (per 100 people)

Source: World Bank (2009)

Proposed by: Lai (2007)

Primary enrollment

Definition: Primary school enrollment (in percent, gross)

Source: World Bank (2009)

Proposed by: Kurrild-Klitgaard et al. (2006)

Secondary enrollment

Definition: Secondary school enrollment (in percent, gross)

Source: World Bank (2009)

Proposed by: Azam and Thelen (2008), Drakos and Gofas (2006a), Kurrild-Klitgaard et al. (2006)

Tertiary enrollment

Definition: Tertiary school enrollment (in percent, gross)

Source: World Bank (2009)

Proposed by: Kurrild-Klitgaard et al. (2006), Testas (2004)

Literacy rates

Definition: Literates (in percent of adult population)

Source: Vanhanen (2003)

Proposed by: Blomberg and Hess (2008a), Bravo and Dias (2006), Krueger and Maleckova (2003),

Kurrild-Klitgaard et al. (2006), Tavares (2004)

Gini coefficient

Definition: Gini coefficient

Source: United Nations University (2008)

Proposed by: Abadie (2006), Feldmann and Perälä (2004), Goldstein (2005), Koch and Cranmer (2007), Kurrild-Klitgaard et al. (2006), Li and Schaub (2004), Li (2005), Piazza (2006)

Globalization

Definition: KOF Index of Globalization

Source: Dreher (2006)

Proposed by: Blomberg and Hess $(2008 \mathrm{a}, 2008 \mathrm{~b})^{\mathrm{f}}$ ) , Blomberg and Rosendorff $(2009)^{\mathrm{f}}$,

Braithwaite and Li (2007) $)^{\mathrm{f})}$, Bravo and Dias $(2006)^{\mathrm{f})}$, Burgoon $(2006)^{\mathrm{f})}$,

Campos and Gassebner $(2009)^{\mathrm{f})}$, Crenshaw et al. $(2007)^{\mathrm{f})}$, Drakos and Gofas $(2006 \mathrm{a})^{\mathrm{f}}$,

Kurrild-Klitgaard et al. $(2006)^{\mathrm{f})}$, Li and Schaub $(2004)^{\mathrm{f})}$, Li $(2005)^{\mathrm{f})}$, Robison et al. $\left.(2006)^{\mathrm{f}}\right)$

FDI

Definition: Foreign direct investment, net inflows (in percent of GDP)

Source: World Bank (2009)

Proposed by: Li and Schaub (2004), Robison et al. (2006)

Portfolio investment

Definition: Portfolio investment, equity (DRS, current US\$)/GDP (current US\$)

Source: World Bank (2009)

Proposed by: Li and Schaub (2004)

WTO

Definition: 1 if GATT/WTO membership

Source: http://www.wto.org

Proposed by: Blomberg and Hess (2008b), Blomberg and Rosendorff (2009) 
Table 1 (part 3)

IMF membership

Definition: 1 if IMF membership

Source: http://www.imf.org

Proposed by: Blomberg and Rosendorff (2009)

OECD

Definition: 1 if OECD membership

Source: http://www.oecd.org

Proposed by: Azam and Thelen (2008), Campos and Gassebner (2009), Li and Schaub (2004)

Gvt. consumption

Definition: General government final consumption expenditure (in percent of GDP)

Source: World Bank (2009)

Proposed by: Burgoon (2006), Crenshaw et al. (2007), Robison et al. (2006)

Transfers

Definition: Transfers of income between residents of the reporting country and the rest of the world that carry no provisions for repayment (in percent of GDP)

Source: World Bank (2009)

Proposed by: Burgoon (2006), Crenshaw et al. (2007)

Social contributions

Definition: Social contributions (in percent of revenue)

Source: World Bank (2009)

Proposed by: Burgoon (2006), Crenshaw et al. (2007)

Education spending

Definition: Public spending on education, total (in percent of GDP)

Source: World Bank (2009)

Proposed by: This paper

Economic freedom

Definition: Fraser Economic Freedom Index

Source: Gwartney and Lawson (2008)

Proposed by: Basuchoudhary and Shughart (2010), Kurrild-Klitgaard et al. (2006), Piazza (2008b)

Aid

Definition: Official development assistance and official aid (in percent of GDP)

Source: World Bank (2009)

Proposed by: Azam and Delacroix (2006), Azam and Thelen (2008), Campos and Gassebner (2009), Neumayer and Plümper (2009)

Fuel exports

Definition: Fuel exports

Source: World Bank (2009)

Proposed by: Sambanis (2008)

Primary goods exports

Definition: Agricultural raw materials, food, and ores and metal exports (in percent of merchandise exports)

Source: World Bank (2009), own calculation

Proposed by: Bravo and Dias (2006), Tavares (2004)

Female labor

Definition: Female labor participation rate (in percent of female population ages $>14$ ) 
Table 1 (part 4)

Source: World Bank (2009)

Proposed by: Robison et al. (2006)

Unemployment rate

Definition: Unemployment rate

Source: International Labour Office (2009)

Proposed by: Feldmann and Perälä (2004), Goldstein (2005), Piazza (2006)

Inflation

Definition: GDP deflator (base year varies by country)

Source: World Bank (2009)

Proposed by: Feldmann and Perälä (2004), Piazza (2006)

Urbanization

Definition: Urban population (in percent of total)

Source: World Bank (2009)

Proposed by: Campos and Gassebner (2009), Robison et al. (2006), Tavares (2004)

Population growth

Definition: Population growth (annual in percent)

Source: World Bank (2009)

Proposed by: Dreher and Fischer (2010), Dreher and Gassebner (2008), Piazza (2006)

Youth bulge

Definition: Population ages 15-25 (in percent of population ages >14)

Source: U.S. Census Bureau: International Data Base

Proposed by: Tavares (2004) ${ }^{\mathrm{g})}$, Urdal (2006)

Ethnic tensions

Definition: Degree of tension attributable to racial, nationality, or language divisions. Higher values indicate more tensions

Source: International Country Risk Guide

Proposed by: Abadie (2006) ${ }^{\text {h), i) }}$, Basuchoudhary and Shughart (2010), Blomberg and Hess (2008a) $)^{\mathrm{i})}$, Bravo and Dias $\left.(2006)^{\mathrm{h}}\right)$, Drakos and Gofas (2006a), Dreher and Fischer $\left.(2010)^{\mathrm{h}}\right)$, i),

Goldstein $\left.(2005)^{\mathrm{h}}\right)$, i) , Kurrild-Klitgaard et al. $(2006)^{\mathrm{h}}$, i) , Lai (2007), Piazza (2006) $)^{\mathrm{h})}$, Piazza (2008a) ${ }^{\mathrm{i})}$, Sambanis $(2008)^{\mathrm{h})}$, Tavares $\left.(2004)^{\mathrm{h}}\right)$

Religious tensions

Definition: Suppression of religious freedom. Higher values indicate more tensions

Source: International Country Risk Guide

Proposed by: Abadie (2006) $)^{\mathrm{j}}$, Blomberg and Hess (2008a, 2008b $)^{\mathrm{j})}$, Dreher and Fischer (2010) Goldstein $\left.(2005)^{\mathrm{j}}\right)$, Piazza $\left.(2006,2008 \mathrm{a})^{\mathrm{j}}\right)$, Tavares $(2004)^{\mathrm{j})}$

Fiscal decentralization

Definition: Subnational expenditure share (in percent of total expenditures)

Source: IMF Governments Finance Statistics

Proposed by: Dreher and Fischer (2010, 2011)

Plurality voting system

Definition: 1 if legislative elections based on first-past-the-post

Source: Beck et al. (2001)

Proposed by: Li (2005) 
Table 1 (part 5)

Proportional voting system

Definition: 1 if legislative elections based on proportional representation

Source: Beck et al. (2001)

Proposed by: Li (2005)

Mixed voting system

Definition: 1 if legislature filled through mixed election rules

Source: Beck et al. (2001)

Proposed by: Li (2005)

Empowerment rights

Definition: Index comprising freedom of movement, speech, and religion as well as worker's rights and political participation. Higher values indicate less human rights abuses

Source: Cingranelli and Richards (2006)

Proposed by: Feldmann and Perälä (2004)

Physical integrity

Definition: Index comprising torture, extrajudicial killing, political imprisonment, and disappearance.

Higher values indicate less human rights abuses

Source: Cingranelli and Richards (2006)

Proposed by: Feldmann and Perälä (2004), Walsh and Piazza (2010)

Freedom of the press

Definition: Index quantifying the freedom of the press. Higher values indicate less press freedom

Source: Freedom House (2009b)

Proposed by: Li (2005)

Law and order

Definition: Strength and impartiality of the legal system as well as of the popular observance of the law.

High values indicate more respect for law and order

Source: International Country Risk Guide

Proposed by: This paper

Military in politics

Definition: Military participation in government. Higher values indicate less military involvement

Source: International Country Risk Guide

Proposed by: This paper

Military leader

Definition: 1 if the chief executive is a military officer

Source: Beck et al. (2001)

Proposed by: This paper

Government fractionalization

Definition: Probability that two randomly chosen deputies from among the government parties will be of different parties

Source: Beck et al. (2001)

Proposed by: Dreher and Fischer (2010, 2011), Dreher and Gassebner (2008), Koch and Cranmer (2007), Piazza (2006)

Opposition fractionalization

Definition: Probability that two randomly chosen deputies belonging to the opposition parties will be of different parties

Source: Beck et al. (2001)

Proposed by: Dreher and Fischer (2010), Piazza (2006) 
Table 1 (part 6)

Left government

Definition: 1 if party of the chief executive is communist, socialist, social democratic, or left-wing

Source: Beck et al. (2001)

Proposed by: Burgoon (2006), Crenshaw et al. (2007), Koch and Cranmer (2007)

Right government

Definition: 1 if party of the chief executive is conservative, Christian democratic, or rightwing

Source: Beck et al. (2001)

Proposed by: Koch and Cranmer (2007)

Centrist government

Definition: 1 if party of the chief executive is centrist

Source: Beck et al. (2001)

Proposed by: Koch and Cranmer (2007)

Regime durability

Definition: No. of years since most recent regime change (three point change in the Polity IV score over a period of three years or less)

Source: Marshall and Jaggers (2002)

Proposed by: Campos and Gassebner (2009), Li (2005), Piazza (2007, 2008a, 2008b)

Demonstrations

Definition: Any peaceful public gathering of at least 100 people for the primary purpose of displaying or voicing their opposition to government policies or authority, excluding demonstrations of a distinctly anti-foreign nature

Source: Databanks International (2005)

Proposed by: Campos and Gassebner (2009)

Strikes

Definition: Any strike of 1000 or more industrial or service workers that involves more than one employer and that is aimed at national government policies or authority

Source: Databanks International (2005)

Proposed by: Campos and Gassebner (2009)

Riots

Definition: Any violent demonstration or clash of more than 100 citizens involving the use of physical force

Source: Databanks International (2005)

Proposed by: Campos and Gassebner (2009)

Guerrilla war

Definition: Any armed activity, sabotage, or bombings carried on by independent bands of citizens or irregular forces and aimed at the overthrow of the present regime

Source: Databanks International (2005)

Proposed by: Campos and Gassebner (2009)

Interstate war

Definition: 1 if war between two or more states with at least 1000 battle-related deaths per year

Source: UCDP/PRIO Conflict Database

Proposed by: Braithwaite and Li (2007), Burgoon (2006), Crenshaw et al. (2007),

Dreher and Fischer (2010), Koch and Cranmer (2007), Lai (2007), Li and Schaub (2004), Li (2005),

Piazza (2008a), Walsh and Piazza (2010) 
Table 1 (part 7)

Internal war

Definition: 1 if war between the government of a state and internal opposition groups without intervention from other states with at least 1000 battle-related deaths per year

Source: UCDP/PRIO Conflict Database

Proposed by: Campos and Gassebner (2009), Lai (2007), Piazza (2007, 2008a, 2008b), Testas (2004), Walsh and Piazza (2010)

Internationalized internal war

Definition: 1 if war between the government of a state and internal opposition groups with intervention from other states with at least 1000 battle-related deaths per year

Source: UCDP/PRIO Conflict Database

Proposed by: Campos and Gassebner (2009), Lai (2007), Piazza (2007, 2008a, 2008b), Testas (2004), Walsh and Piazza (2010)

International organizations

Definition: No. of international organizations in which a country participates

Source: Dreher (2006)

Proposed by: Bravo and Dias (2006)

No of embassies

Definition: No. of embassies in the country

Source: Dreher (2006)

Proposed by: Bravo and Dias (2006)

Political proximity to U.S.

Definition: Share of votes in the UN General Assembly which is cast in line with the United States (i.e., sum of votes in line with United States divided by total votes in a year; abstentions/absences treated as 0.5)

Source: Voeten and Merdzanovic (2009)

Proposed by: Campos and Gassebner (2009), Dreher and Fischer (2010, 2011),

Dreher and Gassebner (2008)

Military personnel

Definition: Armed forces personnel (in percent of total labor force)

Source: World Bank (2009)

Proposed by: Braithwaite and Li $(2007)^{\mathrm{k})}$, Burgoon $(2006)^{\mathrm{k})}$, Crenshaw et al. (2007), Koch and Cranmer $(2007)^{\mathrm{k})}, \mathrm{Li}$ and Schaub $(2004)^{\mathrm{k})}, \mathrm{Li}(2005)^{\mathrm{k})}$

Military expenditures

Definition: Military expenditure (in percent of GDP)

Source: World Bank (2009)

Proposed by: Braithwaite and Li $(2007)^{\mathrm{k})}$, Burgoon $(2006)^{\mathrm{k})}$, Crenshaw et al. (2007), Koch and Cranmer $(2007)^{\mathrm{k})}, \mathrm{Li}$ and Schaub $(2004)^{\mathrm{k})}, \mathrm{Li}(2005)^{\mathrm{k})}$

Arms exports

Definition: Arms imports (in percent of merchandise imports)

Source: World Bank (2009), own calculation

Proposed by: Neumayer and Plümper (2009)

Arms imports

Definition: Arms exports (in percent of merchandise exports)

Source: World Bank (2009), own calculation

Proposed by: Neumayer and Plümper (2009) 
Table 1 (part 8)

\section{State sponsor}

Definition: Countries determined by the U.S. Secretary of State to have repeatedly provided support for acts of international terrorism

Source: U.S. Department of State

Proposed by: Lai (2007)

a) Total GDP; ${ }^{\text {b) }}$ variable is part of composite indicators human development index or gvt. capability; ${ }^{c)}$ political rights; ${ }^{\text {d) }}$ civil liberties; ${ }^{\text {e) }}$ other variable such as executive constraint, pluralism, reg. of political part. or other; ${ }^{\mathrm{f})}$ globalization is measured as openness $((X+M) / \mathrm{GDP})$; $\left.^{\mathrm{g}}\right)$ population ages $\left.<15{ }^{\mathrm{h}}\right)$ ethnic fractionalization; ${ }^{\text {i) }}$ linguistic fractionalization; ${ }^{j}$ ) religious fractionalization; ${ }^{k}$ ) variable is part of the composite indicator gvt. capability

\section{Empirical method}

As the literature overview has well documented there is a large set of studies that investigate the determinants of terrorism which produced a long list of potential explanatory variables. Studies often restrict their analysis to certain subsets of these variables and frequently ignore the effects of any omitted variable bias when other variables are not included. Moreover, using alternative sources of terror data might yield different conclusions regarding the impact of certain variables. In addition to any model uncertainty, the limited number of observations often restricts the power of statistical tests that rule out irrelevant explanatory variables.

In order to address these issues we use extreme bounds analysis (EBA), as proposed by Leamer (1983) and Levine and Renelt (1992). EBA enables us to identify explanatory variables that are robustly related to the three different terrorism measures we use. It is a relatively neutral way of coping with the problem of selecting variables for an empirical model in situations where there are conflicting or inconclusive suggestions in the literature. Originally, EBA was introduced in the economic growth literature (e.g., Leamer 1983; Levine and Renelt 1992; Sala-i-Martin 1997; Sturm and de Haan 2005). In recent years its use has expanded to other fields where there is no clear consensus about which variables belong in a "true" model. Recent examples of topics subjected to the EBA procedure include the determinants of corruption (Serra 2006), life satisfaction (Bjørnskov et al. 2008), democracy (Gassebner et al. 2011) and R\&D investment (Wang 2010).

To conduct an EBA, equations of the following general form are estimated

$$
Y=\beta_{M} M+\beta_{F} F+\beta_{Z} Z+v,
$$

where $Y$ is the dependent variable, $M$ is a vector of "commonly accepted" explanatory variables and $F$ is a vector containing the variables of interest. The vector $Z$ contains up to three possible additional explanatory variables (as in Levine and Renelt 1992) which, according to the broader literature, are related to the dependent variable. The error term is $v$. The EBA test for variable $F$ states that if the lower extreme bound for $\beta_{F}$-i.e., the smallest value for $\beta_{F}$ minus two standard deviations-is negative, while the upper extreme bound for $\beta_{F}$-i.e., the largest value for $\beta_{F}$ plus two standard deviations-is positive, the variable $F$ is not robustly related to $Y$. This basically means that all coefficients in all regressions run need to be statistically significant with a coefficient of the same sign.

Sala-i-Martin (1997) argues that the testing criterion proposed by Leamer (1983) and Levine and Renelt (1992) is far too strong for any variable to pass it. If the distribution of the parameter of interest has both positive and negative support, then a researcher is bound 
to find at least one regression model for which the estimated coefficient turns out to be statistically insignificant if enough regressions are run. Consequently, in what follows we concentrate not on the extreme bounds, but rather on the percentage of the regressions in which the coefficient of the variable $F$ is statistically different from zero. Moreover, instead of analyzing only the extreme bounds of the estimates of the coefficient of a particular variable, we follow Sala-i-Martin's (1997) suggestion and analyze the entire distribution. Accordingly, we also report the median parameter estimate of $\beta_{F}$ and its cumulative distribution function (CDF). The latter represents the proportion of the cumulative distribution function lying on each side of zero. CDF identifies the larger of the areas under the density function either above or below zero, i.e., whether this happens to be CDF or $1-$ CDF. So CDF always lies between 0.5 and 1.0. However, in contrast to Sala-i-Martin, we use the unweighted, instead of the weighted, CDF. ${ }^{5}$ As an alternative to the original criterion proposed by Leamer (1983) and Levine and Renelt (1992), Sala-i-Martin (1997) suggests considering a variable to be robust if the CDF criterion is greater than 0.9 .

Another objection to EBA is that the initial partition of variables into the $M$ and in the $Z$ vector is likely to be arbitrary. However, as pointed out by Temple (2000), there is no reason why standard model selection procedures (such as testing down from a general specification) cannot be used in advance to identify variables that are particularly relevant. Furthermore, some variables are included in the large majority of studies and are by now common in this branch of the literature.

In our view, the inclusion of GDP per capita, population size, and a measure for democracy in the $M$ vector is the minimal commonly agreed set in the literature. The role of GDP per capita has been widely and controversially discussed. As our dependent variable is an unscaled count variable, it seems necessary to control for differences in population sizes. Moreover, the role of democracy is also at the center of the discussion. In particular many studies call for a non-linear effect of democracy. To accommodate this we incorporate two dummy variables for partial and full democracies with full autocracies being the reference group. While it is tempting to include a larger set of variables in the $M$ matrix, we restrict ourselves to the variables the inclusion of which is indeed basically uncontested in the literature. Moreover, in line with the bulk of the literature we include annual time fixed effects in all our regressions to control for common shocks and the cyclical behavior of terrorism (on the latter see, e.g., Im et al. 1987; Enders et al. 1992; Enders and Sandler 1999, 2006b). The $F$ vector contains 62 variables (see Table 1) one at a time. In order to test one particular variable, combinations of the remaining 61 variables form the $Z$ vector. After calculating the relevant statistics the next variable serves as the $F$ vector and the previously tested variable goes into the $Z$ vector.

As mentioned before all our dependent variables are count variables. Many countries in the world experience little terrorism or have few citizens who engage in terrorism; some countries, however, are exposed to many terror events. Thus all our terrorism measures exhibit over-dispersion, i.e., their variances are larger than their means. This calls for a negative binomial estimator. Moreover, we employ panel data and, as mentioned above, terrorism is distributed quite unequally across the globe. We therefore employ a conditional fixed effects negative binomial estimator. Following Hausman et al. (1984), if the joint probability

\footnotetext{
${ }^{5}$ Sala-i-Martin (1997) proposes using the integrated likelihood function to construct a weighted CDF. However, missing observations for some of the variables pose a problem. Sturm and de Haan (2002) show that the goodness-of-fit measure may not be a good indicator of the probability that a model is the true model and that the weights constructed in this way are not invariant to linear transformations of the dependent variable. Hence, changing scales could result in different outcomes and conclusions. We therefore restrict our attention to the unweighted version.
} 
is conditioned on the observed sum of counts (i.e., all observed terror occurrences) for each country then the conditional log likelihood function takes the following form:

$$
\begin{aligned}
\ln L= & \sum_{i=1}^{n}\left[\ln \Gamma\left(\sum_{t=1}^{T_{i}} e^{\left(\beta^{\prime} X_{i t}\right)}\right)+\ln \Gamma\left(\sum_{t=1}^{T_{i}} y_{i t}+1\right)-\ln \Gamma\left(\sum_{t=1}^{T_{i}} e^{\left(\beta^{\prime} X_{i t}\right)}+\sum_{t=1}^{T_{i}} y_{i t}\right)\right. \\
& \left.+\sum_{t=1}^{T}\left\{\ln \Gamma\left(e^{\left(\beta^{\prime} X_{i t}\right)}+y_{i t}\right)-\ln \Gamma\left(e^{\left(\beta^{\prime} X_{i t}\right)}\right)-\ln \Gamma\left(y_{i t}+1\right)\right\}\right] .
\end{aligned}
$$

where $\Gamma$ is the gamma distribution. The country specific effect drops out by conditioning on the sum of the counts of the dependent variable. The coefficients can be obtained by standard maximization of the log likelihood.

The list of all variables, their definitions, sources, and the studies proposing them is given in Table 1 . We do not include two widely used composite indicators, the UN development index and the government capability index. Both indices combine GDP per capita with a large number of other variables. The weights of these indicators are arbitrary and have controversial implications. For example, combining GDP per capita in logarithms with life expectancy in levels implicitly values gains in life expectancy in rich countries as worth much more than an identical gain in life expectancy in poor countries. Therefore, we prefer to include the constitutive parts of these indicators separately. However, we do include composite indicators, such as the KOF Index of Globalization, that use more advanced aggregation procedures such as principal component analysis.

For the dependent variable we employ the three most commonly used datasets on terrorism: ITERATE, GTD, and MIPT. The ITERATE dataset is maybe the most often used dataset on transnational terrorism. It is based on published reports of transnational terrorist incidents found in print and electronic media. We use the version updated through 2005 taken from Mickolus et al. (2006). ${ }^{6}$ While ITERATE is the oldest of the commonly used dataset, the Global Terrorism Database GTD, one of the newest datasets is catching up ground. ${ }^{7}$ This stems from the fact that it is available without monetary costs. Moreover, it differs from the ITERATE dataset as it combines domestic with transnational terrorism. It does not enable the researcher to separate the two forms of terror. ${ }^{8}$ Finally, we use the Memorial Institute for the Prevention of Terrorism (MIPT) Terrorism Knowledge Base dataset. ${ }^{9}$

\footnotetext{
${ }^{6}$ ITERATE defines terrorism as "the use, or threat of use, of anxiety-inducing, extranormal violence for political purposes by any individual or group, whether acting for or in opposition to established governmental authority, when such action is intended to influence the attitudes and behavior of a target group wider than the immediate victims and when, through the nationality or foreign ties of its perpetrators, its location, the nature of its institutional or human victims, or the mechanics of its resolution, its ramifications transcend national boundaries" (Mickolus et al. 2006).

${ }^{7}$ Available at: http://www.start.umd.edu/gtd. The Global Terrorism Database defines terror as "the threatened or actual use of illegal force and violence by a non state actor to attain a political, economic, religious, or social goal through fear, coercion, or intimidation" (http://www.start.umd.edu/gtd/usinggtd/). From 1998 onwards two of the following three criteria had to be fulfilled to be counted as an act of terror: (a) The violent act was aimed at attaining a political, economic, religious, or social goal; (b) The violent act included evidence of an intention to coerce, intimidate, or convey some other message to a larger audience (or audiences) other than the immediate victims; and (c) The violent act was outside the precepts of International Humanitarian Law.

${ }^{8}$ Enders et al. (2011) analytically separate the terror events reported in the GTD into domestic and transnational terror events.

${ }^{9}$ The MIPT Terrorism Knowledge Base defines terrorism as "violence, or the threat of violence, calculated to create an atmosphere of fear and alarm." The focus of terrorism is to discourage the opposition from acting
} 
This was once one of the most popular datasets (as it also was offered without monetary costs) but ceased operation on March 31, 2008. ${ }^{10}$ Due to the many studies which have used this dataset we include it in our analysis, nonetheless. To ensure comparability with the previous studies we chose 1980 - the median start year of the 43 studies—as the initial year for our empirical analysis. Our results have thus little to say on the determinants of the leftist terrorism of the 1970s. ${ }^{11}$

\section{Results}

\subsection{Locations of terrorism}

We present our results in a compact way in Table 2 . We only report variables that passed Sala-i-Martin's (1997) criterion of being considered a robust variable, i.e., a CDF of 0.9 or higher, at least in one measure of terrorism. The complete results are reported in Table A1 in the Appendix.

Two variables appear to be robust across all three measures: the index measuring physical integrity rights and (absence of) religious tensions. Three variables pass the robustness criterion twice, the population size (which is one of the base variables), economic freedom, and the infant mortality rate, while 13 additional variables pass the test in one terror measure only. We have marked the CDFs above 0.9 in bold face to enable the reader to get a quick overview.

According to the results in Table 2, law and order-the strength and impartiality of the legal system — and physical integrity rights — the absence of human rights abuses - are associated with less terrorism. These results contribute to the debate of permissive versus preventive factors of democracy. One view holds that impartiality and respect of human rights enables terrorism, the other view contends that a partisan legal system and human rights violations create grievances and provoke political violence. The results reported in Table 2 are consistent with the latter view. However, law and order also measures popular observance of the law and human rights violations may be the result rather than the cause of terrorism (Dreher et al. 2010). Therefore, the possibility of reverse causality prevents strong conclusions.

The robust and negative relationship between infant mortality and the occurrence of terrorism defies the popular view that terrorism is rooted in poverty. Our results suggest that it is not so much the lack of material resources that is important for terrorism but rather the lack of economic opportunities: Countries that restrict economic freedom experience more terrorism. Somewhat surprisingly and in contrast to the majority of previously reported results, we find that financial globalization measured by foreign portfolio investments is positively correlated with terrorism. Urbanization is positively associated with terrorism. This finding is in accordance with much of the earlier literature-both empirical and theoretical. Cities provide an abundance of targets and attacks in cities are more likely to get media coverage than attacks in sparsely populated rural areas.

with free will. The motives for engaging in terrorism are political, while the acts themselves are generally conducted in a way that will achieve maximum publicity.

${ }^{10}$ Since 2009 a successor database called the RAND Database of Worldwide Terrorism Incidents is available.

${ }^{11}$ We have replicated our results using all available observations and using an alternative GDP PPP measure (from Penn World Tables). Our results remain virtually unchanged. 
Table 2 Main results for locations of terrorism

\begin{tabular}{|c|c|c|c|c|c|c|c|c|c|}
\hline \multirow[t]{2}{*}{ Variable } & \multicolumn{3}{|c|}{ Location, ITERATE } & \multicolumn{3}{|c|}{ Location, GTD } & \multicolumn{3}{|c|}{ Location, MIPT } \\
\hline & Coef. & $\mathrm{CDF}$ & $\%$ sig. & Coef. & $\mathrm{CDF}$ & $\%$ sig. & Coef. & $\mathrm{CDF}$ & $\%$ sig. \\
\hline \multicolumn{10}{|l|}{ Baseline variables } \\
\hline GDP per capita, log & 0.103 & 0.681 & 39.6 & 0.210 & 0.894 & 73.4 & 0.063 & 0.628 & 27.6 \\
\hline Population, log & 0.142 & 0.837 & 62.3 & 0.221 & 0.984 & 93.7 & 0.177 & 0.902 & 68.8 \\
\hline Democracy & 0.059 & 0.550 & 23.7 & 0.191 & 0.646 & 48.9 & -0.065 & 0.537 & 14.7 \\
\hline Partial democracy & 0.035 & 0.542 & 20.9 & 0.225 & 0.726 & 53.0 & -0.017 & 0.523 & 10.2 \\
\hline \multicolumn{10}{|l|}{ Robust variables } \\
\hline Physical integrity & -0.138 & 0.979 & 92.1 & -0.165 & 0.970 & 90.8 & -0.099 & 0.914 & 73.5 \\
\hline Religious tension & 0.103 & 0.934 & 80.6 & 0.121 & 0.986 & 96.3 & 0.069 & 0.918 & 74.6 \\
\hline Economic freedom & -0.307 & 0.948 & 80.0 & -0.269 & 0.949 & 83.0 & -0.327 & 0.899 & 71.7 \\
\hline Infant mortality & -0.017 & 0.910 & 67.2 & -0.010 & 0.903 & 64.1 & -0.008 & 0.699 & 22.4 \\
\hline Ethnic tensions & -0.007 & 0.544 & 18.4 & 0.040 & 0.911 & 63.1 & 0.011 & 0.627 & 15.2 \\
\hline Gvt. fractionalization & 0.450 & 0.867 & 64.9 & 0.420 & 0.919 & 73.5 & 0.411 & 0.852 & 60.8 \\
\hline Guerrilla war & 0.208 & 0.877 & 65.7 & 0.370 & 0.990 & 96.0 & 0.182 & 0.893 & 62.3 \\
\hline Internal war & 0.086 & 0.839 & 46.5 & 0.264 & 0.987 & 95.6 & 0.112 & 0.856 & 62.4 \\
\hline Internat. internal war & 0.028 & 0.624 & 6.5 & 0.147 & 0.933 & 69.6 & 0.059 & 0.735 & 14.0 \\
\hline Law and order & 0.002 & 0.538 & 11.6 & -0.072 & 0.960 & 82.3 & -0.059 & 0.882 & 62.8 \\
\hline Military expenditures & 0.027 & 0.701 & 29.1 & 0.079 & 0.935 & 79.8 & 0.015 & 0.625 & 17.2 \\
\hline Military personnel & 0.041 & 0.791 & 32.2 & 0.077 & 0.923 & 73.1 & 0.025 & 0.691 & 21.5 \\
\hline OECD & -0.108 & 0.600 & 14.2 & 0.407 & 0.914 & 68.4 & 0.137 & 0.661 & 11.0 \\
\hline Portfolio investment & 1.029 & 0.743 & 7.4 & 0.037 & 0.539 & 1.8 & 2.877 & 0.963 & 80.4 \\
\hline Proximity to U.S. & 1.266 & 0.813 & 42.8 & 1.481 & 0.905 & 72.0 & 0.969 & 0.795 & 34.6 \\
\hline Strikes & 0.068 & 0.810 & 37.6 & 0.126 & 0.906 & 75.5 & 0.088 & 0.897 & 53.1 \\
\hline Urbanization & 0.015 & 0.856 & 62.7 & 0.005 & 0.716 & 42.3 & 0.023 & 0.913 & 77.5 \\
\hline
\end{tabular}

Note: The table reports the median parameter estimates (Coef.), the cumulative distribution function (CDF), i.e. the proportion of the cumulative distribution function lying on each side of zero, and the percent the estimate was statistically significant at the $5 \%$ level (\% sig.). The criterion to consider a variable robustly related to terrorism is a CDF above 0.9 which is printed in bold face

Several researchers expect ethnically and religiously diverse societies as well as ethnic and religious tensions to provide fertile ground for terrorism (see Sect. 2 and Table 1). Our results suggest that this is indeed the case. In line with most of the previous evidence we find religious and ethnic tensions to have a positive effect on the number of terrorist attacks in a country and year.

Terrorism is also related to other forms of political violence and internal conflicts such as strikes, guerrilla war as well as internal and internationalized internal wars, i.e., civil wars. These findings are consistent with the notions that other forms of political violence are an expression of the same underlying grievances, that civil wars provide fertile training ground for terrorists, and that terrorism is the strategy of the weaker belligerent in asymmetric warfare. The robust association between terrorism and military personnel and expenditures points in the same direction.

Many studies find that "the Western World" is often the victim of terrorism because it is rich and influential. Our results confirm this notion as we find OECD member countries to be attacked more often. 
Related to the above is the notion that the United States is a prime target because of the values it represents particularly attracting fundamental terrorism. This is nicely summarized by Zakaria (2004): "What worries people around the world above all else is living in a world shaped and dominated by one country-the [United States]." Thus if a government sides with the United States it also puts itself at risk. In the literature this is operationalized by the voting behavior in the UN General Assembly. Savun and Philips (2009) generalize this idea by showing that involvement in foreign policy predicts transnational terror attacks. According to the EBA voting in line with the United States indeed triggers terror attacks.

Domestic political struggles and resulting social cleavages might translate into an increased level of terror when the struggles escalate. This transmission channel has been documented by several studies and is confirmed by our results.

There are interesting differences in the patterns of robustness across different datasets. In particular, ethnic tensions and OECD membership are robustly associated only with terrorism for GTD. To a lesser extent, this is also the case for other forms of political violence, military power, government fractionalization and political proximity to the United States. These differences are consistent with the notion that ethnic tensions, political struggles and social cleavages are much more important for domestic rather than transnational terrorism. GTD measures both forms of terrorism, while ITERATE and MIPT focus exclusively on transnational terrorism. ${ }^{12}$ Other differences between the datasets may also contribute to the discrepancies in the results. For example, ITERATE excludes attacks against combatants and military targets in wars, major military interventions, and military occupations; GTD includes them. Hence, exploiting disparities between domestic and transnational terrorism as well as across datasets seems to be a promising avenue for future research (see Enders et al. 2011 for a thorough comparison of the datasets and a decomposition of the GTD data into domestic and transnational terror incidents).

As the previous discussion made clear, there are some robust correlates of terrorism. However, the most striking of our findings is that the majority of the variables suggested in the literature do not survive EBA. Our approach is pretty extreme and is important to reiterate four caveats: Our results do not necessarily invalidate theories of terrorism associated with other variables or empirical strategies. The lack of robustness may result from the use of poor proxies, the inclusion of "bad controls," inconsistencies associated with endogenous regressors, or restriction to reduced form estimations.

\subsection{Victims and perpetrators}

The main results for the victim- and perpetrator-regressions are reported in Table 3, the complete results can be found in Table A1 in the Appendix. Note that the perpetrator is not identified in GTD but only in ITERATE.

Overall, the set of robust variables in regressions on victim- and perpetrator-countries is not too different than regressions on terror-locations. Among the baseline variables population size and to a lesser extent GDP per capita are again robustly associated with terrorism.

Given the great deal of intellectual resources invested in research on the relationship between terrorism and democracy, one of the most important finding is the lack of a robust relationship between terrorism and democracy. From a theoretical perspective, there are two countervailing effects of democracy on terrorism. Democracy lowers the direct costs of engaging in terrorist activities but increases its relative costs. Moreover, existing empirical

\footnotetext{
${ }^{12}$ MIPT tracks domestic terrorism from 1998 onward. We focus on transnational terrorism only to ensure comparability with ITERATE.
} 
Table 3 Main results for victims and perpetrators of terrorism

\begin{tabular}{|c|c|c|c|c|c|c|c|c|c|}
\hline \multirow[t]{2}{*}{ Variable } & \multicolumn{3}{|c|}{ Victim, ITERATE } & \multicolumn{3}{|c|}{ Victim, GTD } & \multicolumn{3}{|c|}{ Perpetrator, ITERATE } \\
\hline & Coef. & $\mathrm{CDF}$ & $\%$ sig. & Coef. & $\mathrm{CDF}$ & $\%$ sig. & Coef. & $\mathrm{CDF}$ & $\%$ sig. \\
\hline \multicolumn{10}{|l|}{ Baseline variables } \\
\hline GDP per capita, log & 0.304 & 0.852 & 58.5 & 0.371 & 0.957 & 87.9 & -0.020 & 0.528 & 21.0 \\
\hline Population, $\log$ & 0.307 & 0.965 & 90.0 & 0.247 & 0.990 & 96.6 & 0.111 & 0.774 & 38.8 \\
\hline Democracy & -0.111 & 0.599 & 10.6 & -0.018 & 0.512 & 40.1 & -0.327 & 0.755 & 37.9 \\
\hline Partial Democracy & -0.196 & 0.741 & 21.7 & 0.041 & 0.556 & 29.1 & -0.110 & 0.629 & 23.3 \\
\hline \multicolumn{10}{|l|}{ Robust variables } \\
\hline Economic freedom & -0.313 & 0.938 & 83.3 & -0.202 & 0.914 & 73.0 & -0.374 & 0.954 & 82.1 \\
\hline Internat. internal war & 0.188 & 0.963 & 85.1 & 0.134 & 0.927 & 70.3 & 0.169 & 0.906 & 60.5 \\
\hline Physical integrity & -0.101 & 0.969 & 85.2 & -0.137 & 0.935 & 82.4 & -0.198 & 0.985 & 93.5 \\
\hline Guerrilla war & 0.098 & 0.766 & 28.2 & 0.366 & 0.993 & 97.2 & 0.325 & 0.935 & 77.5 \\
\hline Internal war & 0.170 & 0.930 & 73.7 & 0.270 & 0.987 & 95.1 & 0.126 & 0.874 & 59.7 \\
\hline Telephone & 0.006 & 0.720 & 16.9 & 0.019 & 0.934 & 80.7 & -0.026 & 0.904 & 72.8 \\
\hline Centrist government & 0.117 & 0.783 & 30.2 & -0.069 & 0.721 & 20.8 & 0.294 & 0.936 & 63.0 \\
\hline Ethnic tensions & -0.007 & 0.582 & 7.5 & 0.039 & 0.909 & 65.2 & -0.006 & 0.527 & 12.5 \\
\hline Military expenditures & 0.026 & 0.643 & 10.5 & 0.074 & 0.917 & 78.5 & 0.028 & 0.648 & 18.5 \\
\hline OECD & -0.345 & 0.789 & 33.0 & 0.717 & 0.976 & 90.4 & -0.329 & 0.729 & 28.1 \\
\hline Proximity to U.S. & 0.854 & 0.758 & 28.6 & 2.233 & 0.968 & 88.8 & 1.377 & 0.801 & 38.9 \\
\hline Primary goods exports & -0.006 & 0.786 & 34.4 & -0.007 & 0.930 & 72.7 & 0.001 & 0.536 & 10.6 \\
\hline Religious tensions & 0.063 & 0.841 & 62.5 & 0.124 & 0.987 & 96.7 & 0.071 & 0.858 & 58.3 \\
\hline Youth bulge & -4.604 & 0.830 & 58.5 & -4.504 & 0.930 & 78.9 & 1.398 & 0.619 & 26.1 \\
\hline
\end{tabular}

Note: The table reports the median parameter estimates (Coef.), the cumulative distribution function (CDF), i.e. the proportion of the cumulative distribution function lying on each side of zero, and the percent the estimate was statistically significant at the 5\% level (\% sig.). The criterion to consider a variable robustly related to terrorism is a CDF above 0.9 which is printed in bold face

evidence is also conflicting with some studies reporting negative, some positive and some nonlinear effects (see Sect. 2). Our results show why this is the case. The CDFs are often close to 0.5 , which implies that the coefficient estimates are distributed with mean zero. At the same time, there is a relatively high percentage of statistically significant coefficients - at least for some dependent variables and datasets. Thus, either statistically significant positive or statistically significant negative relationships between democracy and terrorism can be found with the appropriate set of controls.

The findings for five (groups of) variables closely resemble the results for the regressions using the location-aspect of terrorism. First, there is a very robust negative relationship between economic freedom and terrorism. Second, respect for physical integrity rights goes hand in hand with low levels of terrorism. Third, terrorism is closely associated with other forms of conflicts such as civil and guerrilla wars. Again, the positive relationship between military expenditures and terrorism points in the same direction. Fourth, ethnic and religious tensions are positively related to terrorism. Finally, citizens from Western countries, i.e., OECD members and countries politically close to the United States, are more likely to be victimized by terrorism. The results for ethnic and religious tensions, military expenditures, as well as for OECD membership and political proximity to the United States are slightly less robust in estimates based on the ITERATE dataset. 
In comparison with the results reported in Table 2, a couple of new results emerge from Table 3. First, in contrast to what might be expected from the natural resource curse literature, fewer attacks against citizens from a country occur, the larger the share of primary goods among the country's exports. Second, citizens from countries with a large share of young people are less likely to be victimized and, importantly, not more likely to commit attacks. Especially the latter result contradicts the literature on "youth bulge". Third, the number of telephone mainlines in a country is negatively associated with the number of attacks perpetrated by citizens of that country. On the one hand, this result may be regarded as evidence for the conjecture that terrorism is rooted in economic grievances and poor development. On the other hand, the number of terrorist attacks perpetrated by citizens of a particular country is less robustly but positively associated with other common indicators of development such as infant health, life expectancy, literacy rates, and primary and secondary school enrollment (see Table A1 in the Appendix). Finally, more terrorist attacks are perpetrated by citizens from countries with centrist governments that from country-years under left- or right-wing regimes. This finding is rather unexpected. In our estimation sample about $45 \%$ of the perpetrators are active under centrist governments. Greece, Portugal, Spain, and Sri Lanka seem to be of particular importance for this result. Yet the results are not driven by individual countries. If we repeatedly run regressions with excluding one country at a time, the coefficient estimates for centrist governments are relatively stable and range from 0.134 (without Portugal) to 0.238 (without Mozambique).

\section{Conclusions}

Terrorism has substantial costs, both economic (e.g., Frey et al. 2007, 2009; Gaibulloev and Sandler 2008; Enders 2007; Sandler and Enders 2008; Llussa and Tavares 2011) as well as political (e.g., Gassebner et al. 2008, 2012). Therefore, in many countries the fight against terrorism is one of the top priorities on the political agenda. Two different strategies can be pursued in the fight against terrorism. One is to address the root causes of terrorism, another to treat its symptoms with specific counterterrorism measures. Scientific evidence can guide political decision makers in both cases. There is a small but important strand of literature assessing specific counterterrorism measures (e.g., Landes 1978; Enders et al. 1990a, 1990b; Enders and Sandler 1993; Sandler et al. 2011). A much larger strand of literature investigates conditions at the level of societies and countries that are conducive to terrorism. This strand of the literature can potentially inform policies aiming at curing the root causes. It is this second strand of the literature that we assessed in this paper.

Our systematic robustness analysis of previous findings yields some important policy implications. Among the most important findings are two non-results. First, terrorist activity is not robustly associated with the degree of democracy. What is more, our estimate lay bare the reason behind the conflicting results presented in the previous literature. For most datasets and aspects of terrorism, coefficient estimates are distributed with a mean close to zero. At the same time, the estimated coefficients turn out to be statistically significantly different from zero relatively often. Thus, either statistically significant positive or statistically significant negative relationships between democracy and terrorism can be found with the appropriate set of controls. Second, economic development as measured by GDP per capita does not matter for the amount of terrorism. This finding mirrors research analyzing the socioeconomic background of terrorists which finds little evidence that the typical terrorist is poor (e.g., Krueger and Maleckova 2003; Berrebi 2007; Krueger 2007). There is some conflicting evidence for other measures of development. 
While infant mortality is negatively associated with the number of attacks occurring in a country and year, the number of telephone mainlines is also negatively related to the number of attacks perpetrated by citizens from a particular country. However, the preponderance of evidence suggests that the level of economic development is of minor importance at best.

However, there is a very robust negative relationship between the degree of economic freedom and terrorism. Thus, more important than the level of development are economic opportunities.

According to our analysis, a strong and impartial judicial system and respect of physical integrity rights are associated with low levels of terrorism. This suggests that the widely purported trade-off between respecting human rights and countering terrorism may be nonexistent. However, because of the obvious possibility of reverse causality, this interpretation has to be taken with a grain of salt.

A number of robust correlates of terrorism emerge from our analysis. Some can be a guideline for policy measures to counter terrorism, however, many are beyond governments' control. The prevention of civil and guerrilla wars and other forms of conflict as well as a reduction of ethnic and religious tensions are all worthy goals irrespective of their effect on the level of terrorism. Similarly, few will seriously consider sacrificing Western values in the name of security.

We probed the robustness of previous findings on the determinants of terrorism along three dimensions: aspects of terrorism, datasets and set of control variables. Our results have several implications for future research in this area. First, our analysis uncovers some truly robust correlates of terrorism. Yet, additional theoretical and empirical studies are needed to clarify issues of causality and underlying mechanisms. Second, our analysis demonstrates just how sensitive are the existing empirical results. Therefore, systematic robustness tests are warranted in future research on the determinants of terrorism. Our results suggest a set of variables that belongs in all analyses of robustness. Third, previous studies differ along additional dimensions than the ones considered here, such as alternative measures of terrorism, domestic versus transnational terrorism, and time periods. It is worth studying how choices along these dimensions influence results. Some authors suggest using measures of terrorism that reflect the severity of attacks (e.g., number of casualties). Severe attacks may be associated with factors other than those that explain less severe ones. Our analysis does not speak to this issue. Or, differences may exist between the determinants of domestic versus transnational terrorism. The sharp contrast between the results based on GTD, which combines domestic and transnational terrorist incidents and results based on the other two datasets focusing on transnational terrorism points in this direction. The decomposition of the GTD data into domestic and transnational terrorism by Enders et al. (2011) and other datasets including domestic terrorism provide a means of tackling this important issue. Similarly, time may matter. For example, Enders and Sandler (2000) show that the rise of religious terrorism after the takeover of the U.S. embassy in Tehran in 1979 and the end of the Cold War in 1991 substantially changed the nature of terrorism. In the same vein, Basuchoudhary and Shughart (2010) provide evidence consistent with the notion terrorism is influenced by different factors during and after the Cold War.

In sum, there are a number of intriguing questions left for future research. We hope that the analysis presented in this article provides a solid foundation on which future research on the determinants of terrorism can build.

Acknowledgements For comments and suggestions, we thank Axel Dreher, Todd Sandler and participants of the Fourth Terrorism and Policy Conference at the University of Texas at Dallas, the European Public Choice Society meeting at Rennes and the annual meetings of the Swiss and German Economic Associations in Lucerne and Frankfurt, respectively. 


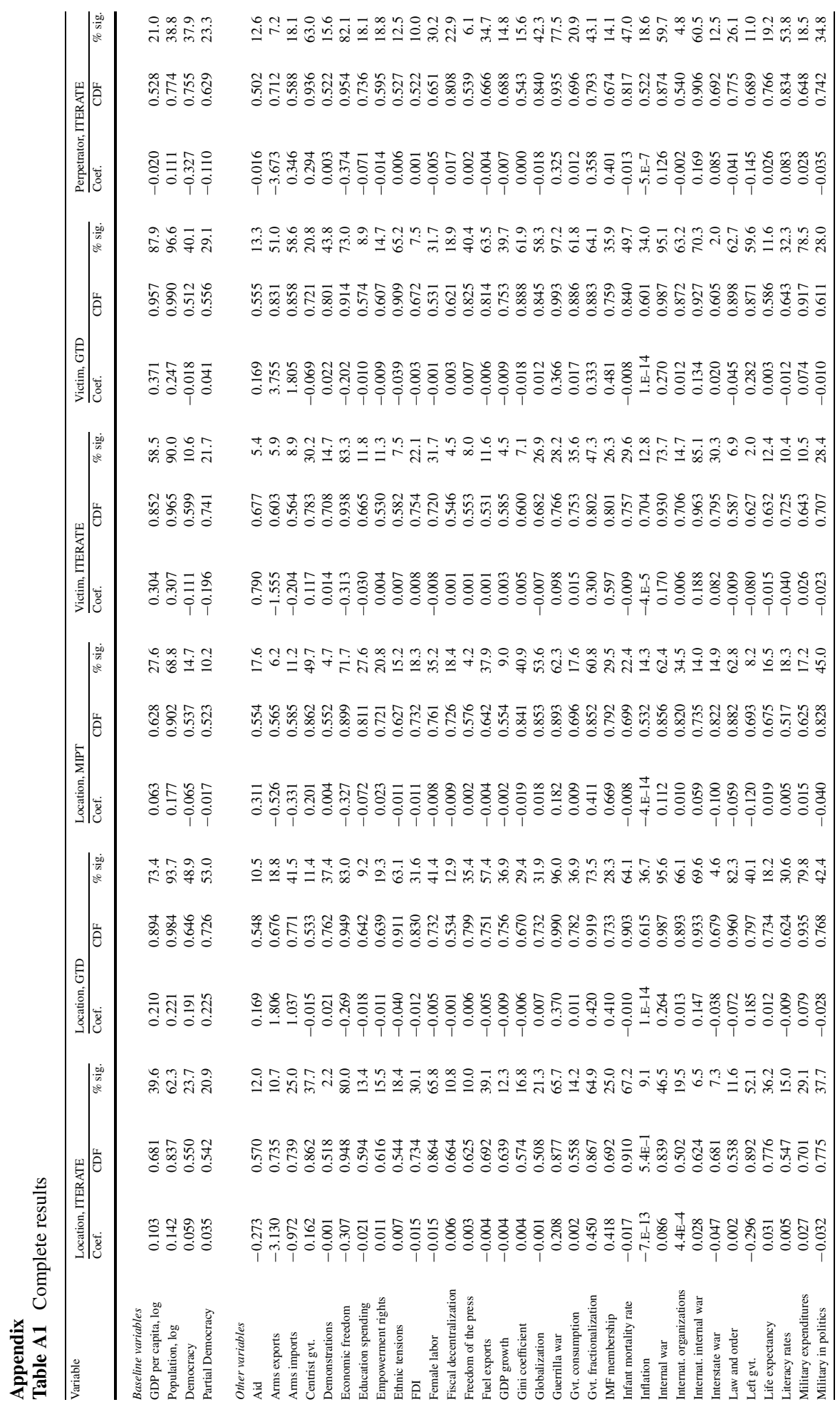




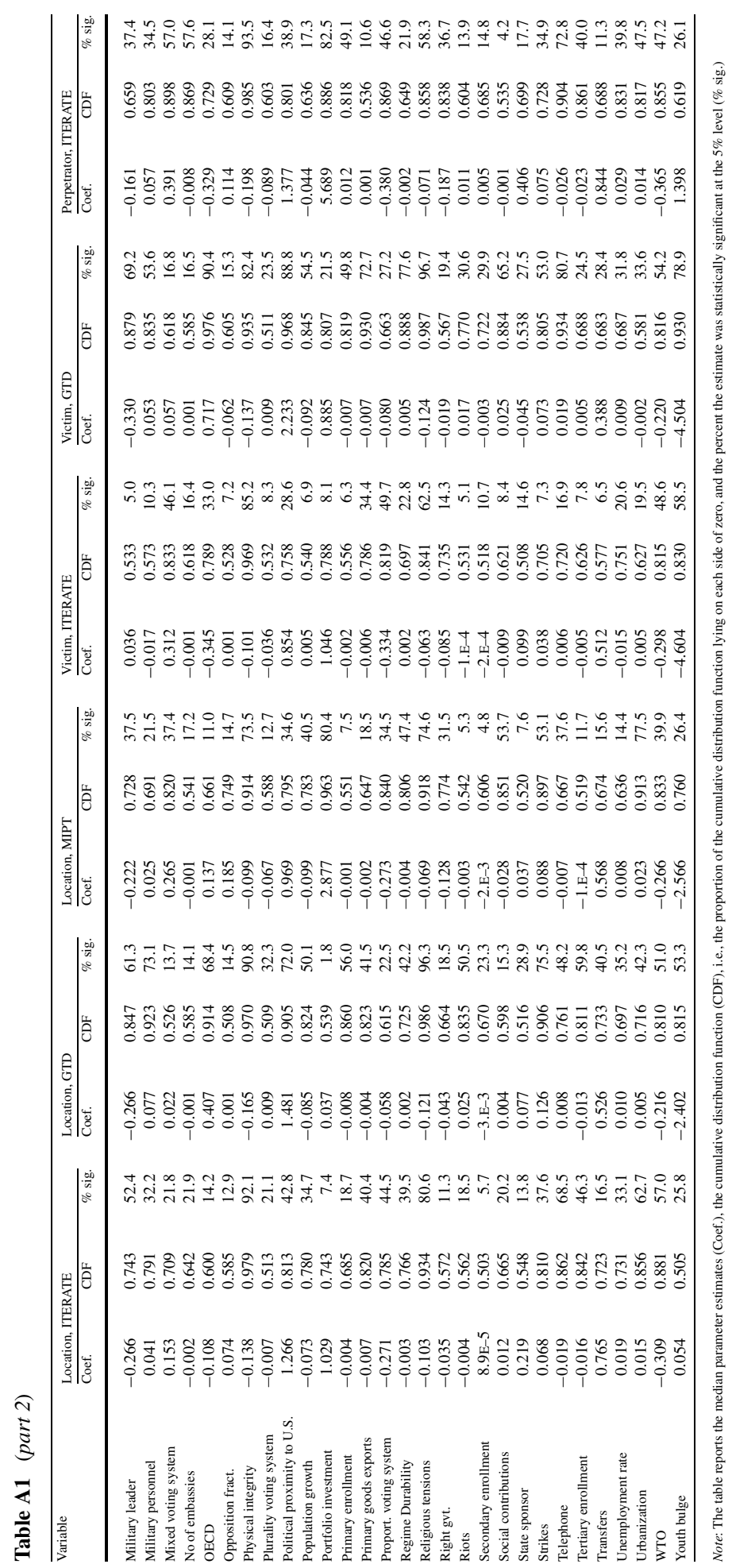




\section{References}

Abadie, A. (2006). Poverty, political freedom, and the roots of terrorism. American Economic Review, 96(2), $50-56$.

Ai, C., \& Norton, E. C. (2003). Interaction terms in logit and probit models. Economics Letters, 80(1), 123129.

Angrist, D., \& Pischke, J. S. (2009). Mostly harmless econometrics: an empiricist's companion. Princeton: Princeton University Press.

Azam, J.-P., \& Delacroix, A. (2006). Aid and the delegated fight against terrorism. Review of Development Economics, 10(2), 330-344.

Azam, J.-P., \& Thelen, V. (2008). The roles of foreign aid and education in the war on terror. Public Choice, 135(3), 375-397.

Basuchoudhary, A., \& Shughart, W. F. (2010). On ethnic conflict and the origins of transnational terrorism. Defence and Peace Economics, 21(1), 65-87.

Beck, T., Clarke, G. R. G., Groff, A., Keefer, P., \& Walsh, P. (2001). New tools in comparative political economy: the database of political institutions. World Bank Economic Review, 15(1), 165-176.

Berman, E., \& Laitin, D. D. (2008). Religion, terrorism and public goods: testing the club model. Journal of Public Economics, 92(10-11), 1942-1967.

Berrebi, C. (2007). Evidence about the link between education, poverty and terrorism among Palestinians. Peace Economics, Peace Science and Public Policy, 13(1), 1-36.

Bjørnskov, C., Dreher, A., \& Fischer, J. A. V. (2008). Cross-country determinants of life satisfaction: exploring different determinants across groups in society. Social Choice and Welfare, 30(1), 119-173.

Blomberg, S. B., \& Hess, G. D. (2008a). The Lexus and the olive branch: globalization, democratization and terrorism. In P. Keefer \& N. Loayza (Eds.), Terrorism, economic development, and political openness (pp. 116-147). Cambridge: Cambridge University Press.

Blomberg, S. B., \& Hess, G. D. (2008b). From (no) butter to guns? Understanding the economic role in transnational terrorism. In P. Keefer \& N. Loayza (Eds.), Terrorism, economic development, and political openness (pp. 83-115). Cambridge: Cambridge University Press.

Blomberg, S. B., Hess, G. D., \& Weerapana, A. (2004). Economic conditions and terrorism. European Journal of Political Economy, 20(2), 463-478.

Blomberg, S. B., \& Rosendorff, B. P. (2009). A gravity model of globalization, democracy and transnational terrorism. In G. D. Hess (Ed.), Guns and butter (pp. 25-156). Cambridge: MIT Press.

Braithwaite, A., \& Li, Q. (2007). Transnational terrorism hot spots: identification and impact evaluation. Conflict Management and Peace Science, 24(4), 281-296.

Bravo, A. B. S., \& Dias, C. M. M. (2006). An empirical analysis of terrorism: deprivation, islamism and geopolitical factors. Defence and Peace Economics, 17(4), 329-341.

Burgoon, B. (2006). On welfare and terror: social welfare policies and political-economic roots of terrorism. Journal of Conflict Resolution, 50(2), 176-203.

Bush, G. W. (2002). Remarks by the President at the United Nations financing for development conference. White House press release, March 22, 2002. http://www.whitehouse.gov/news/releases/ 2002/03/20020322-1.html.

Campos, N. F., \& Gassebner, M. (2009). International terrorism, political instability and the escalation effect. CEPR Discussion Paper 7226.

Cingranelli, D. L., \& Richards, D. L. (2006). The Cingranelli-Richards (CIRI) human rights dataset 2006. http://www.humanrightsdata.org/.

Crenshaw, M. (1981). The causes of terrorism. Comparative Politics, 13(4), 379-399.

Crenshaw, E., Robison, K., \& Jenkins, J. C. (2007). The “roots" of transnational terrorism: a replication and extension of Burgoon. Paper presented to the annual meetings of the American Sociological Association, New York City (August 2007).

Databanks International (2005). Cross-national time-series data archive, 1815-2003. Binghamton.

Doran, M. S. (2002). Somebody else's civil war. Foreign Affairs, 81(1), 22-42.

Drakos, K., \& Gofas, A. (2006a). In search of the average transnational terrorist attack venue. Defence and Peace Economics, 17(2), 73-93.

Drakos, K., \& Gofas, A. (2006b). The devil you know but are afraid to face: underreporting bias and its distorting effects on the study of terrorism. Journal of Conflict Resolution, 50(5), 714-735.

Dreher, A. (2006). Does globalization affect growth? Evidence from a new index of globalization. Applied Economics, 38(10), 1091-1110.

Dreher, A., \& Fischer, J. A. V. (2010). Government decentralization as a disincentive for transnational terror? An empirical analysis. International Economic Review, 51(4), 981-1002.

Dreher, A., \& Fischer, J. A. V. (2011). Does government decentralization reduce domestic terror? An empirical test. Economics Letters, 113(3), 223-225. 
Dreher, A., \& Gassebner, M. (2008). Does political proximity to the US cause terror? Economics Letters, 99(1), 27-29.

Dreher, A., Gassebner, M., \& Siemers, L. (2010). Does terror threaten human rights? Evidence from panel data. Journal of Law and Economics, 53(1), 65-93.

Enders, W. (2007). Terrorism: an empirical analysis. In T. Sandler \& K. Hartley (Eds.), Handbook of defense economics (Vol. 2, pp. 815-866). Amsterdam: Elsevier.

Enders, W., Parise, G., \& Sandler, T. (1992). A time-series analysis of transnational terrorism: trends and cycles. Defence Economics, 3(4), 305-320.

Enders, W., \& Sandler, T. (1993). The effectiveness of anti-terrorism policies: vector-autoregression intervention analysis. American Political Science Review, 87(4), 829-844.

Enders, W., \& Sandler, T. (1999). Transnational terrorism in the post-Cold War era. International Studies Quarterly, 43(1), 145-167.

Enders, W., \& Sandler, T. (2000). Is transnational terrorism becoming more threatening? A time-series investigation. Journal of Conflict Resolution, 44(3), 307-332.

Enders, W., \& Sandler, T. (2006a). The political economy of terrorism. Cambridge: Cambridge University Press.

Enders, W., \& Sandler, T. (2006b). Distribution of transnational terrorism among countries by income class and geography after 9/11. International Studies Quarterly, 50(2), 367-393.

Enders, W., Sandler, T., \& Cauley, J. (1990a). U.N. conventions, technology and retaliation in the fight against terrorism: an econometric evaluation. Terrorism and Political Violence, 2(1), 83-105.

Enders, W., Sandler, T., \& Cauley, J. (1990b). Assessing the impact of terrorist-thwarting policies: an intervention time series approach. Defence Economics, 2(1), 1-18.

Enders, W., Sandler, T., \& Gaibulloev, K. (2011). Domestic versus transnational terrorism: data, decomposition, and dynamics. Journal of Peace Research, 48(3), 319-337.

Eubank, W. L., \& Weinberg, L. (1994). Does democracy encourage terrorism? Terrorism and Political Violence, 6(4), 417-435.

Eubank, W. L., \& Weinberg, L. (2001). Terrorism and democracy: perpetrators and victims. Terrorism and Political Violence, 13(1), 155-164.

Eyerman, J. (1998). Terrorism and democratic states: soft targets or accessible systems? International Interactions, 24(2), 151-170.

Feldmann, A. E., \& Perälä, M. (2004). Reassessing the causes of nongovernmental terrorism in Latin America. Latin American Politics and Society, 46(2), 101-132.

Freedom House (2009a). Freedom in the world 2009: the annual survey of political rights and civil liberties. Washington: Freedom House.

Freedom House (2009b). Freedom of the press 2009. Washington: Freedom House.

Frey, B. S., \& Luechinger, S. (2003). How to fight terrorism: alternatives to deterrence. Defence and Peace Economics, 14(4), 237-249.

Frey, B. S., Luechinger, S., \& Stutzer, A. (2007). Calculating tragedy: assessing the costs of terrorism. Journal of Economic Surveys, 21(1), 1-24.

Frey, B. S., Luechinger, S., \& Stutzer, A. (2009). The life satisfaction approach to valuing public goods: the case of terrorism. Public Choice, 138(3-4), 317-345.

Gaibulloev, K., \& Sandler, T. (2008). Growth consequences of terrorism in Western Europe. Kyklos, 61(3), 411-424.

Gassebner, M., Jong-A-Pin, R., \& Mierau, J. (2008). Terrorism and electoral accountability: one strike, you're out! Economics Letters, 100(1), 126-129.

Gassebner, M., Jong-A-Pin, R., \& Mierau, J. (2012). Terrorism and cabinet duration. International Economic Review, forthcoming.

Gassebner, M., Lamla, M. J., \& Vreeland, J. R. (2011). Extreme bounds of democracy. Journal of Conflict Resolution, forthcoming.

Gassebner, M., \& Luechinger, S. (2011). Lock, stock, and barrel: a comprehensive assessment of the determinants of terror. CESifo Working Paper No. 3550. Munich: CESifo

Goldstein, K. B. (2005). Unemployment, inequality and terrorism: another look at the relationship between economics and terrorism. Undergraduate Economic Review, 1(1), Article 6.

Greene, W. (2010). Testing hypotheses about interaction terms in nonlinear models. Economics Letters, 107(2), 291-296.

Gwartney, J. G., \& Lawson, R. A. (2008). Economic freedom of the world: 2008 annual report. Vancouver: Fraser Institute.

Hausman, J., Hall, B., \& Griliches, Z. (1984). Economic models for count data with an application to the patents-R\&D relationship. Econometrica, 52(4), 909-938.

Hoover, K. D., \& Perez, S. J. (2004). Truth and robustness in cross-country growth regressions. Oxford Bulletin of Economics and Statistics, 66(5), 765-798. 
Im, E. I., Cauley, J., \& Sandler, T. (1987). Cycles and substitutions in terrorist activities: a spectral approach. Kyklos, 40(2), 238-255.

International Labour Office (ILO) (2009). LABORSTA database. Geneva: ILO.

Koch, M. T., \& Cranmer, S. (2007). Testing the "Dick Cheney" hypothesis: do governments of the left attract more terrorism than governments of the right? Conflict Management and Peace Science, 24(3), 311326.

Krieger, T., \& Meierrieks, D. (2011). What causes terrorism? Public Choice, 147(1), 3-27.

Krueger, A. B. (2007). What makes a terrorist? Economics and the roots of terrorism. Princeton: Princeton University Press.

Krueger, A. B., \& Laitin, D. D. (2008). Kto kogo? A cross-country study of the origins and targets of terrorism. In P. Keefer \& N. Loayza (Eds.), Terrorism, economic development, and political openness (pp. 148-173). Cambridge: Cambridge University Press.

Krueger, A. B., \& Maleckova, J. (2003). Education, poverty and terrorism: is there a causal connection? Journal of Economic Perspectives, 17(4), 119-144.

Krueger, A. B., \& Maleckova, J. (2009). Attitudes and action: public opinion and the occurrence of international terrorism. Science, 325(5947), 1534-1536.

Kurrild-Klitgaard, P., Justesen, M. K., \& Klemmensen, R. (2006). The political economy of freedom, democracy and transnational terrorism. Public Choice, 128(1), 289-315.

Lai, B. (2007). "Draining the swamp": an empirical examination of the production of international terrorism 1968-1998. Conflict Management and Peace Science, 24(4), 297-310.

Landes, W. M. (1978). An economic study of U.S. aircraft hijackings, 1961-1976. Journal of Law and Economics, 21(1), 1-31.

Leamer, E. E. (1983). Let's take the con out of econometrics. American Economic Review, 73(1), 31-43.

Levine, R., \& Renelt, D. (1992). A sensitivity analysis of cross-country growth regressions. American Economic Review, 82(4), 942-963.

Li, Q. (2005). Does democracy promote or reduce transnational terrorist incidents? Journal of Conflict Resolution, 49(2), 278-297.

Li, Q., \& Schaub, D. (2004). Economic globalization and transnational terrorism: a pooled time-series analysis. Journal of Conflict Resolution, 48(2), 230-258.

Llussá, F., \& Tavares, J. (2011). Which terror at which cost? On the economic consequences of terrorist attacks. Economics Letters, 110(1), 52-55.

Marshall, M. G., \& Jaggers, K. (2002). Polity IV project: political regime characteristics and transitions, 1800-2002: dataset users manual. Maryland: University of Maryland.

Medvedev, D. (2011). Opening address to the World Economic Forum in Davos. Kremlin press release, January 26, 2011. http://eng.kremlin.ru/news/1684.

Mickolus, E. F., Sandler, T., Murdock, J. M., \& Flemming, P. (2006). International terrorism: attributes of terrorist events 1968-2005 (ITERATE). Dunn Loring: Vinyard Software.

Neumayer, E., \& Plümper, T. (2009). International terrorism and the clash of civilizations. British Journal of Political Science, 39(4), 711-734.

Piazza, J. A. (2006). Rooted in poverty? Terrorism, poor economic development, and social cleavages. Terrorism and Political Violence, 18(1), 159-177.

Piazza, J. A. (2007). Draining the swamp: democracy promotion, state failure, and terrorism in 19 Middle Eastern countries. Studies in Conflict and Terrorism, 30(6), 521-539.

Piazza, J. A. (2008a). Do democracy and free markets protect us from terrorism? International Politics, 45(1), $72-91$.

Piazza, J. A. (2008b). Incubators of terror: do failed and failing states promote transnational terrorism? International Studies Quarterly, 52(3), 469-488.

Plümper, T., \& Neumayer, E. (2010). The friend of my enemy is my enemy: international alliances and international terrorism. European Journal of Political Research, 49(1), 75-96.

Robison, K. K., Crenshaw, E. M., \& Jenkins, J. C. (2006). Ideologies of violence: the social origins of islamist and leftist transnational terrorism. Social Forces, 84(4), 2009-2026.

Sala-i-Martin, X. (1997). I just ran two million regressions. American Economic Review, 87(2), 178-183.

Sambanis, N. (2008). Terrorism and civil war. In P. Keefer \& N. Loayza (Eds.), Terrorism, economic development, and political openness (pp. 174-208). Cambridge: Cambridge University Press.

Sandler, T. (1995). On the relationship between democracy and terrorism. Terrorism and Political Violence, 7(4), 1-9.

Sandler, T., \& Arce, D. G. (2007). Terrorism: a game theoretic approach. In T. Sandler \& K. Hartley (Eds.), Handbook of defense economics (pp. 775-813). Amsterdam: Elsevier.

Sandler, T., Arce, D. G., \& Enders, W. (2011). An evaluation of INTERPOL's cooperative-based counterterrorism linkages. Journal of Law and Economics, 54(1), 79-110. 
Sandler, T., \& Enders, W. (2004). An economic perspective on transnational terrorism. European Journal of Political Economy, 20(2), 301-316.

Sandler, T., \& Enders, W. (2008). Economic consequences of terrorism in developed and developing countries: an overview. In P. Keefer \& N. Loayza (Eds.), Terrorism, economic development, and political openness (pp. 17-47). Cambridge: Cambridge University Press.

Savun, B., \& Phillips, B. J. (2009). Democracy, foreign policy, and terrorism. Journal of Conflict Resolution, 53(6), 878-904.

Serra, D. (2006). Empirical determinants of corruption: a sensitivity analysis. Public Choice, 126(1), 225256.

Shughart, W. F. (2011). Terrorism in rational choice perspective. In C. J. Coyne \& R. L. Mathers (Eds.), The handbook on the political economy of war (pp. 126-153). Cheltenham: Edward Elgar.

Sturm, J.-E., \& de Haan, J. (2002). How robust is Sala-i-Martin's robustness analysis? Mimeo. University of Konstanz.

Sturm, J.-E., \& de Haan, J. (2005). Determinants of long-term growth: new results applying robust estimation and extreme bounds analysis. Empirical Economics, 30(3), 597-617.

Tavares, J. (2004). The open society assesses its enemies: shocks, disasters and terrorist attacks. Journal of Monetary Economics, 51(5), 1039-1070.

Temple, J. (2000). Growth regressions and what the textbooks don't tell you. Bulletin of Economic Research, 52(3), 181-205.

Testas, A. (2004). Determinants of terrorism in the Muslim world: an empirical cross-sectional analysis. Terrorism and Political Violence, 16(2), 253-273.

The Economist (2010). Economic focus: exploding misconceptions. The Economist (December 18) 130.

United Nations University (2008). UNU-WIDER World Income Inequality Database, Version 2.0c, May 2008.

Urdal, H. (2006). A clash of generations? Youth bulges and political violence. International Studies Quarterly, 50(3), 607-629.

Vanhanen, T. (2003). Democratization: a comparative analysis of 170 countries. London: Routledge.

Voeten, E., \& Merdzanovic, A. (2009). United Nations General Assembly voting data. http://hdl. handle.net/1902.1/12379.

Walsh, J. I., \& Piazza, J. A. (2010). Why respecting physical integrity rights reduces terrorism. Comparative Political Studies, 43(5), 551-577.

Wang, E. C. (2010). Determinants of R\&D investment: the extreme-bounds-analysis approach applied to 26 OECD countries. Research Policy, 39(1), 103-116.

Weinberg, L. B., \& Eubank, W. L. (1998). Terrorism and democracy: what recent events disclose. Terrorism and Political Violence, 10(1), 108-118.

World Bank (2009). World development indicators. CD-Rom. Washington.

Zakaria, F. (2004). The arrogant empire. Newsweek, June 23. 